\title{
PENYULUHAN TENTANG KARYA INOVASI DALAM PENGOLAHAN SAMPAH LIMBAH RUMAH TANGGA MENJADI PUPUK ORGANIK DI DUSUN SUKAJAYA, DESA ANGGADITA KARAWANG TIMUR
}

\author{
${ }^{1}$ Helfi Gustia, ${ }^{2}$ Wira Fazri Rosyidin ${ }^{3}$ Familia Novita, ${ }^{4}$ Elferida Sormin \\ ${ }^{1}$ Universitas Muhammadiyah Jakarta, Jakarta, Indonesia \\ ${ }^{2}$ Universitas Muhammadiyah Prof. Dr. Hamka, Jakarta, Indonesia \\ ${ }^{3,4}$ Universitas Kristen Indonesia, Jakarta, Indonesia \\ 1helfi_umj@yahoo.com \\ 2wira.fazri.r@uhamka.ac.id \\ 3familia.novita@gmail.com \\ eferidasormin@yahoo.com
}

\begin{abstract}
ABSTRAK
Karya inovasi dalam pengolahan sampah limbah rumah tangga menjadi pupuk organik baik cair maupun padatan dilaksanakan di Dusun Sukajaya Desa Anggadita, Karawang Timur, Jawa Barat selama tiga kali kunjungan yakni tanggal 14, 16 dan 23 November 2018. Sampah limbah rumah tangga yang dimanfaatkan adalah sisa makanan, tangkai sayuran, buah-buahan yang sudah membusuk sehingga tidak tidak layak untuk dimakan, kulit bawang, tangkai cabai dan lain sebagainya yang semuanya adalah sisa olahan makanan yang selama ini dibuang begitu saja, sehingga menimbulkan efek samping seperti bau tidak sedap akibat sampah sudah membusuk, bahkan lebih parahnya lagi ketika masyarakat memilih untuk membuang sampah limbah rumahtangga tersebut ke pinggiran sungai Citarum. Untuk itu dilakukan karya inovasi dalam mengolah sampah berupa limbah rumah tangga tersebut sehingga menjadi berdayaguna, dalam hal ini sampah limbah rumahtangga diolah menjadi pupuk organik baik berupa cairan maupun padatan. Pengolahan sampah limbah rumah tangga menjadi pupuk organik dilakukan secara sederhana segingga masyarakat mudah untuk memahami dan menerapkan dalam kegiatan sehari-hari. Dari hasil kegiatan dapat diperoleh data bahwa tingkat antusiasme masyarakat sangat tinggi, mereka memahami cara dan prosedur pengolahan serta berkomitmen untuk menerapkannya dalam aktifitas sehari-hari.
\end{abstract}

Kata Kunci: Inovasi; Limbah; Pupuk Organik

\begin{abstract}
Innovative work in processing household waste into organic and liquid fertilizers, both liquid and solid, was carried out in Dusun Sukajaya, Desa Anggadita, East Karawang, West Java for three visits on 14, 16 and 23 November 2018. Waste household waste used is leftovers, stalks of vegetables, fruits that have decayed so that they are not suitable to be eaten, onion skins, chili stalks, etc. all of which are leftover processed foods which have been thrown away, causing side effects such as bad smell due to decaying garbage, even worse when the community chose to dispose of the household waste from the Citarum river. For this reason, an innovation work is carried out in processing waste in the form of household waste so that it becomes efficient, in this case household waste is processed into organic fertilizer in the form of liquid or solid. The processing of household waste into organic fertilizer is done simply so that people are easy to understand and apply in their daily activities. From the results of the activity data can be obtained that the level of enthusiasm of the community is
\end{abstract}


very high, they understand the methods and procedures of processing and are committed to applying them in daily activities.

Keywords: Innovation; Waste; Organic Fertilizer

\section{PENDAHULUAN}

Sungai Citarum adalah sungai terpanjang yang berada di Propinsi Jawa Barat. Kondisi sungai Citarum sangat memprihatinkan dan merupakan sungai terkotor di dunia. Sungai Citarum memiliki potensi ekonomi, ekologi dan sosial yang sangayt penting di Jawa Barat. S.Citarum dengan luas DPS sekitar 6.600 km2 bersumber dari G. Wayang, Kecamatan Kertasari, Kabupaten Bandung mengalir sepanjang $315 \mathrm{~km}$ ke Laut Jawa dengan melintasi 118 kecamatan pada 7 kabupaten dan 1 kota di Jawa Barat yaitu : Kabupaten Bandung, Sumedang, Cianjur, Purwakarta, Bogor, Bekasi, Karawang dan Kota Bandung.

Hasil pemantauan kualitas air menunjukkan bahwa sampai saat ini kondisi kualitas air Sungai Citarum belum dapat memenuhi baku mutu air yang telah ditetapkan di sepanjang tahun, terutama pada musim kemarau (SK. Gubernur Jabar No. 39/2000). Terjadinya penurunan kualitas air ini diakibatkan oleh meningkatnya pencemaran yang berasal dari populasi penduduk perkembangan industri, ekstensifikasi dan intensifikasi lahan pertanian, pengembangan perikanan, populasi ternak serta eksplorasi bahan tambang /galian. (N.T. Bukit dan I. A. Yusuf, 2002)

Program untuk mengembalikan kebersihan air sungai Citarum telah dimulai sejak tahun 2001 dengan diluncurkannya Program Citarum Bergetar. Salah satu kegiatan Program Citarum Bergetar adalah pembetukan tim investigasi permasalahan DAS Citarum yang bertugas untuk membuat action plan pengendalian kerusakan, pencemaran dan pemulihan DAS Citarum.

Tujuan utama dari Program Citarum Bergetar adalah memperbaiki proses dan kualitas penataan ruang berbasis ekosistem Citarum. Dalam perkembangannya, program Citarum Bergetar berjalan tanpa diketahui tingkat keberhasilannya. Terindikasi, adanya tumpang tindih regulasi yang menjadi penyebab. Faktualnya, DAS Citarum ditangani banyak pihak, mulai pemerintah pusat, provinsi, daerah, serta BUMD dan BUMN. Mengingat, peran sungai sepanjang 297 kilometer ini memang vital.

Program terakhir terkait perbaikan ekosistem sungai Citarum yang digaungkan pada 2013, Gerakan Citarum Bersih, Sehat, Indah dan Lentari (Bestari) yang meleset dari target yang prestisius. Harapannya, di 2018, air Sungai Citarum dapat diminum. Tetapi, sampai saat ini 
kualitasnya belum memenuhi baku mutu air yang telah ditetapkan, sehingga tidak memungkinan untuk dikonsumsi. Menyadari bahwa kelestarian sungai terpanjang dan terbesar di Jawa Barat ini merupakan tanggung jawab seluruh masyarakat yang bermukim di Jawa Barat, pada tahun 2018 dilakukan Program Citarum Harum yang melibatkan sivitas akademika Perguruan Tinggi untuk ikut ambil peran dalam memperbaiki ekosistem Citarum.

Dasar pelaksanaan dari Program Citarum Harum adalah Quick Win 2018 yang terdiri dari 7 kegiatan, yaitu Monitoring Kesehatan Penduduk, Edukasi Pembuangan Sampah, Sanitasi Lingkungan dari Sampah Industri dan Limbah Medis, Program 3 R, Edukasi Hutan Mangrove, Wisata Sungai dan Alih Profesi Menjadi Pelayanan Jasa Perbengkelan, dan Incenerator/Jala Sampah.
Pemerintah, dalam hal ini Menristekdikti memberikan dukungan penuh melalui penyediaan fasilitas riset maupun juga melalui keikutsertaan para akademisi dalam penerapan inovasi untuk mengendalikan DAS Citarum sebagaimana wujud nyata dari Perpres No.15 tahun 2018 tentang Percepatan Pengendalian Pecemaran Dan Kerusakan Ekosistem Daerah Aliran Sungai Citarum, pasal $12 \mathrm{c}$.

Terdapat beberapa wilayah yang berlokasi di daerah aliran sungai Citarum bagian hilir, salah satu adalah Kabupaten Karawang Timur secara khusus desa Anggadita yang merupakan zona merah pencemaran sungai citarum karena merupakan wilayah yang paling banyak industri, dan berbatasan langsung dengan sungai citarum. Dusun Sukajaya, adalah salah satu dusun yang terdapat di desa Anggadita, Kecamatan Klari Kabupaten Karawang Timur.

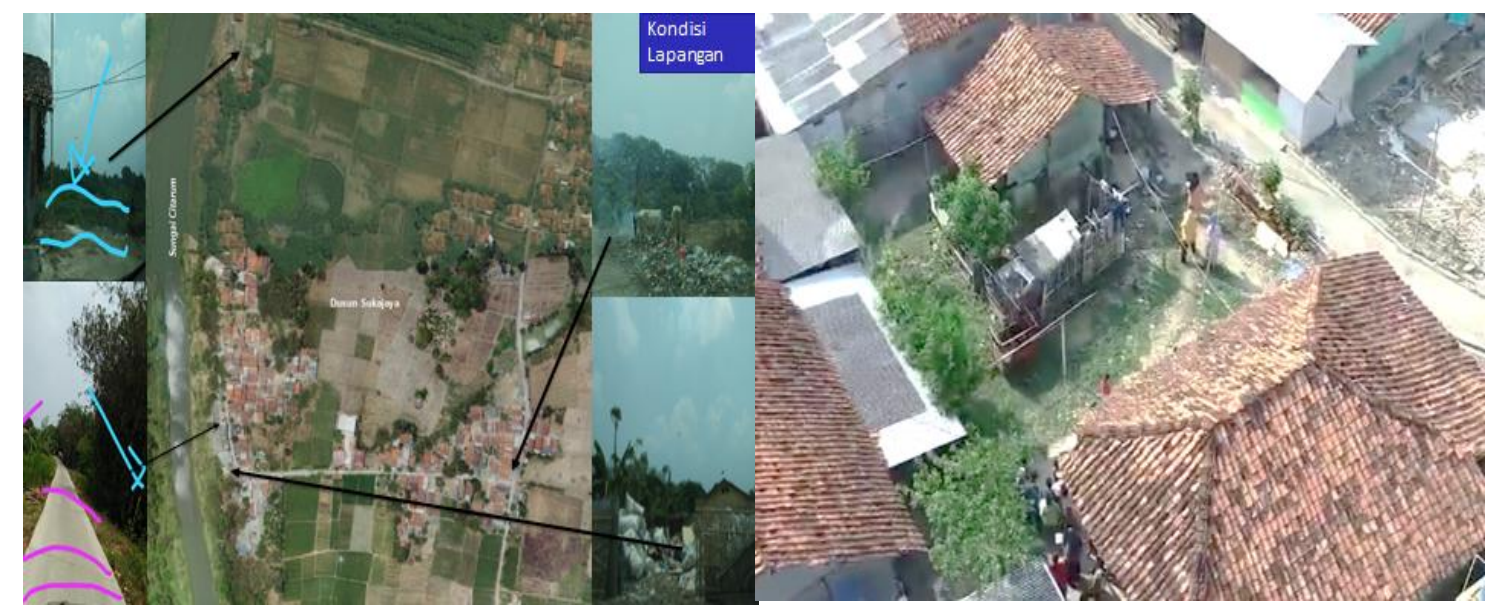

Gambar 1. Peta lokasi dan gabungan foto kondisi lapangan di Desa Sukajaya (by Kamera Drone) 
Beberapa permasalahan di Sungai Citarum di antaranya dicemari oleh sampah rumah tangga, yang sementara di duga paling besar berasal daerah lingkungan masyarakat yang berbatasan langsung dengan sungai Citarum, selain itu permasalahan lainnya adalah sedimentasi dan limbah industry. Oleh karena itu beberapa langkah dipandang sangat perlu dilakukan di nataranya menanamkan kesadaran dalam diri masyarakat bahwa kebersihan sungai Citarum adalah tanggungjawab bersama seluruh lapisan masyarakat, sehingga untuk dapat melibatkan masyarakat secara aktif dalam pemeliharaan kebersihan sungai citarum maka perlu dilakukan sosialisasi tentang bagaimana mengolah sampah rumah tangga sehingga tidak harus dibuang ke sungai citarum.

Pemerintah melalui Lemabaga Layanan Pendidikan Tinggi Wilayah III (LLDikti III) mengeluarkan Surat Keputusan Nomor 628/L3/KM/2018 tentang Penetapan Koordinator Umum, Koordinator Sektor Perguruan Tinggi Pada Pelaksanaan Kuliah Kerja Nyata (KKN) Tematik "Citarum Harum" di Lingkungan Lembaga Layanan Pendiidkan Tinggi Wilayah III Tahun 2018. Di mana dalam surat keputusan tersebut, Universitas Muhammadiyah Jakarta bersama dengan Universitas Kristen Indonesia Jakarta tergabung dalam keanggotaan sektor 18 dengan lokasi pemberdayaan masyarakatnya adalah Desa Anggadita.

\section{Kelompok Sasaran}

Kelompok sasaran dari kegiatan pengabdian kepada masyarakat ini adalah masyarakat Dusun Sukajaya, Desa Anggadita, Kecamatan Klari, Kabupaten Karawang Timur

\section{Tujuan dan Manfaat}

\section{Tujuan}

Adapun yang menjadi tujuan dari kegiatan pengabdian kepada masyarakat ini adalah:

1. Untuk meningkatkan pengetahuan masyarakat Desa Sukajaya tentang pemilahan sampah

2. Untuk meningkatkan kesadaran dan semangat masyarakat Desa Sukajaya untuk mengelola dan mengolah sampah yang bersumber dari rumah tangga sehingga dapat mengurangi dampak pencemaran lingkungan secara khusus di sekitar sungai citarum

\section{Manfaat}

Terciptanya lingkungan yang bersih di Desa Sukajaya, secara khusus sungai citarum yang berbatasan langsung dengan desa tersebut, sehingga fungsi sungai bisa kembali sebagaimana mestinya dan tidak sebaliknya mendatangkan bencana. 


\section{METODE PELAKSANAAN}

Metode yang digunakan dalam kegiatan pengabdian kepada masyarakat ini diawali dengan Pemetaan Masalah yang dilakukan melalui diskusi dengan beberapa lembaga sosial masyarakat yang selama ini sudah aktif melakukan kegiatan di dusun yang lainnya. Selanjutnya melakukan sosialisasi dengan pemangku jabatan di tingkat desa atau kelurahan melalui Minggon, di mana pada tahap ini tim bersama dengan para kepala dusun menyusun langkah-langkah taktis yang akan dikerjalan bersama-sama. Kemudian dilanjutkan dengan sosialisasi dan pelatihan pengolahan sampah limbah rumah tangga menjadi pupuk organik kepada masyarakat, dalam hal ini masyarakat Dusun Sukajaya, Desa Anggadita.

Indikator keberhasilan kegiatan adalah sebagai berikut: masyarakat dusun Sukajaya mengetahui tentang pemilahan sampah, selain itu masyarakat dusun Sukajaya semakin termotivasi untuk mengelola dan mengolah sampah yang bersumber dari rumah tangga.

\section{HASIL DAN PEMBAHASAN}

Kegiatan pengabdian ini diawali dengan pemetaan masalah yang dilakukan pada tanggal 18 Oktober 2018 melalui diskusi dengan pemerintah setempat dan lembaga sosial masyarakat yang sudah aktif menjadi pemerhati sungai citarum yang berlokasi di kantor Desa Anggadita. Dari hasil diskusi diperoleh informasi tentang beberapa pokok besar permasalahan yang berdampak langsung terhadap tercemarnya sungai citarum, salah satu di antaranya adalah pembuangan sampah limbah rumah tangga oleh masyarakat sekitar ke sungai citarum.

Kegiatan selanjutnya atas arahan Bapak Kepala Desa Anggadita, Tim mengikuti acara Minggon pada hari Kamis, 25 Oktober 2018 yang diikuti oleh seluruh kepala dusun yang terdapat di Desa Anggadita. Pada Acara Minggon tersebut, Tim memperoleh beberapa informasi tambahan tentang dusun mana saja yang menjadi prioritas utama dalam pelaksanaan kegiatan. Dari hasil diskusi diperoleh kesepakatan bahwa dusun Sukajaya menjadi dusun pertama yang akan disasar oleh kegiatan pengabdian ini.

Tim yang tergabung dalam sektor 18 dengan koordinator sektor Universitas Mercu Buana dan diikuti oleh anggota sektor yang bergabung dan aktif yaitu tujuh universitas (Universitas Kristen Indonesia, Universitas Muhammadiyah Jakarta, Universitas Muhammadiyah Prof. Dr. Hamka, Universitas Krisnadwipayana, Universitas MH.Thamrin, Institut IImu Sosial dan Manajemen STIAMI dan Sekolah Tinggi IImu Komputer LSPR), yang selanjutnya melakukan diskusi tentang langkah-langkah taktis sekaligus pembagian tugas sesuai dengan kompetensi yang dimiliki oleh masingmasing universitas dalam rangka memberikan solusi terhadap beberapa 
permasalahan yang sudah diklasifikasi bersama pimpinan daerah setempat.

Universitas Kristen Indonesia, Universitas Muhammadiyah Jakarta dan Universitas Muhammadiyah Prof. Dr. Hamka mendapat kesempatan menjadi satu tim yang dipercayakan menangani permasalahan sampah limbah rumah tangga. Berdasarkan penugasan tersebut, ketiga universitas yang diwakili oleh dosen yang ditugaskan oleh masing-masing universitas melakukan diskusi dan persiapan yang matang. Pada tanggal 9 dan 16 November 2018 tim melakukan sosialisasi dan pelatihan tentang karya inovasi dalam pengolahan sampah limbah rumah tanggah menjadi pupuk organik, baik pupuk organik berupa padatan atau bokasi dan juga pupuk organik cair.

Pengolahan sampah limbah rumah tangga menjadi pupuk organik padatan atau bokasi dilakukan dengan beberapa langkah, yakni:
1. Menyiapkan sampah organik (dapat dipotong-potong untuk mempercepat proses)

2. Masukan sampah organik ke wadah (misalnya tong, atau trash bag yang ditutup rapat

3. Pencampuran serbuk gergaji dan/atau serpihan pendukung baha

4. Pencampuran EM4 (bisa dibeli di toko pertanian, membuat sendiri dari urin hewan atau membuat dari larutan air panas, bekatul, terasi, molase yang difermentasi)

5. Tutup rapat dan diamkan 3-5 minggu. Dalam menyimpan dilakukan pembuatan galian untuk menyimpan selama waktu yang ditentukan.

Proses pelaksanaan sebagaimana dalam gambar 2 berikut ini.

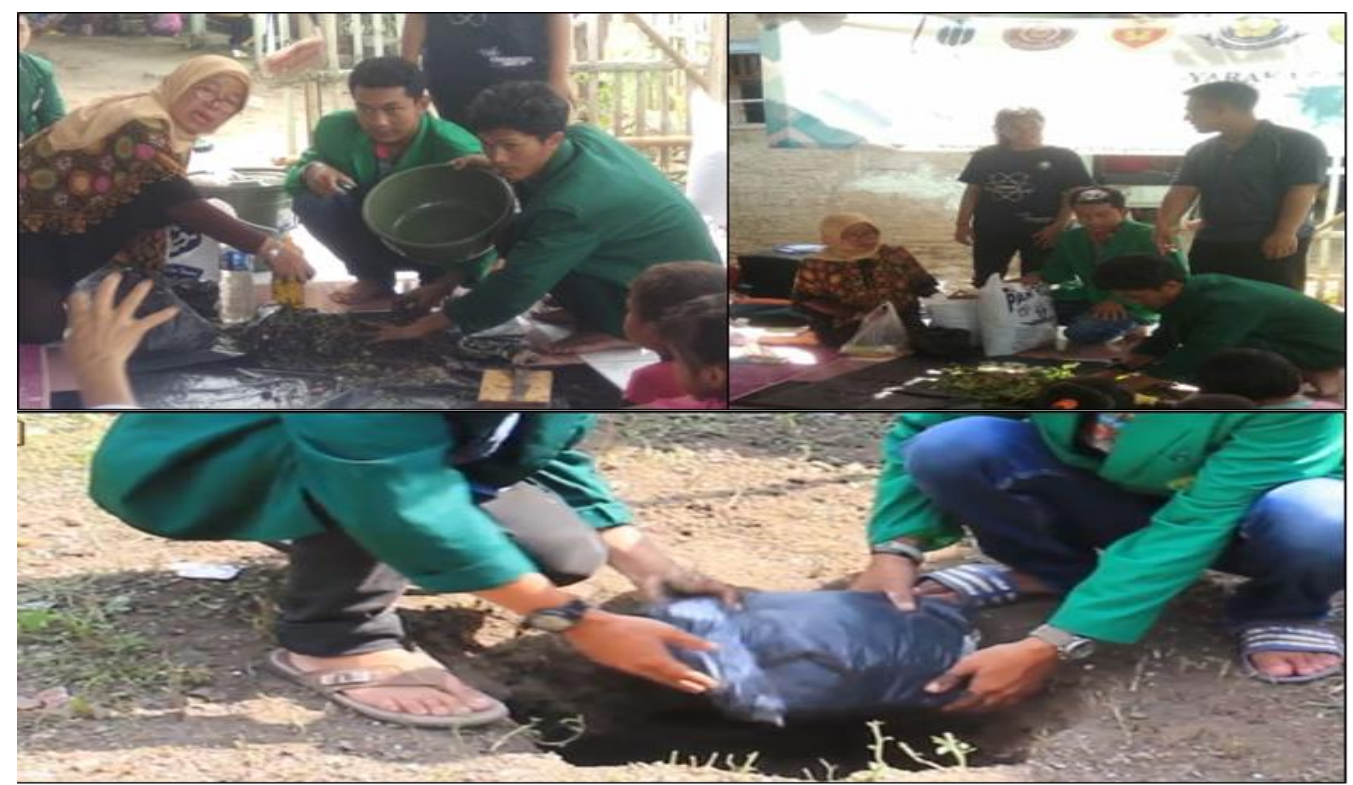

Gambar 2. Proses pengolahan sampah limbah rumah tangga menjadi pupuk organik padat/bokasi 
Selanjutnya pengolahan sampah limbah rumah tangga menjadi pupuk organik cair, dilakukan dengan tahapantahapan sebagai berikut:

1. Proses pencacahan sampah menjadi ukuran yang lebih kecil

2. Penyiapan bahan untuk fermentasi dalam hal ini EM4 yang ditambah dengan bahan lainnya seperti air cucian beras
3. Memasukkan sampah limbah rumah tangga yang sudah dicacah ke dalam tong decomposer yang sudah didesain sedemikian rupa dengan pembatas di dalamnya, sehingga ketika proses penguraian telah terjadi, cairan akan turun ke bawah dan dapat dikeluarkan melalui kran yang sudah di desain sedemikian rupa.

Proses pelaksanaan pengolahan seperti terlihat pada gambar 3 berikut.

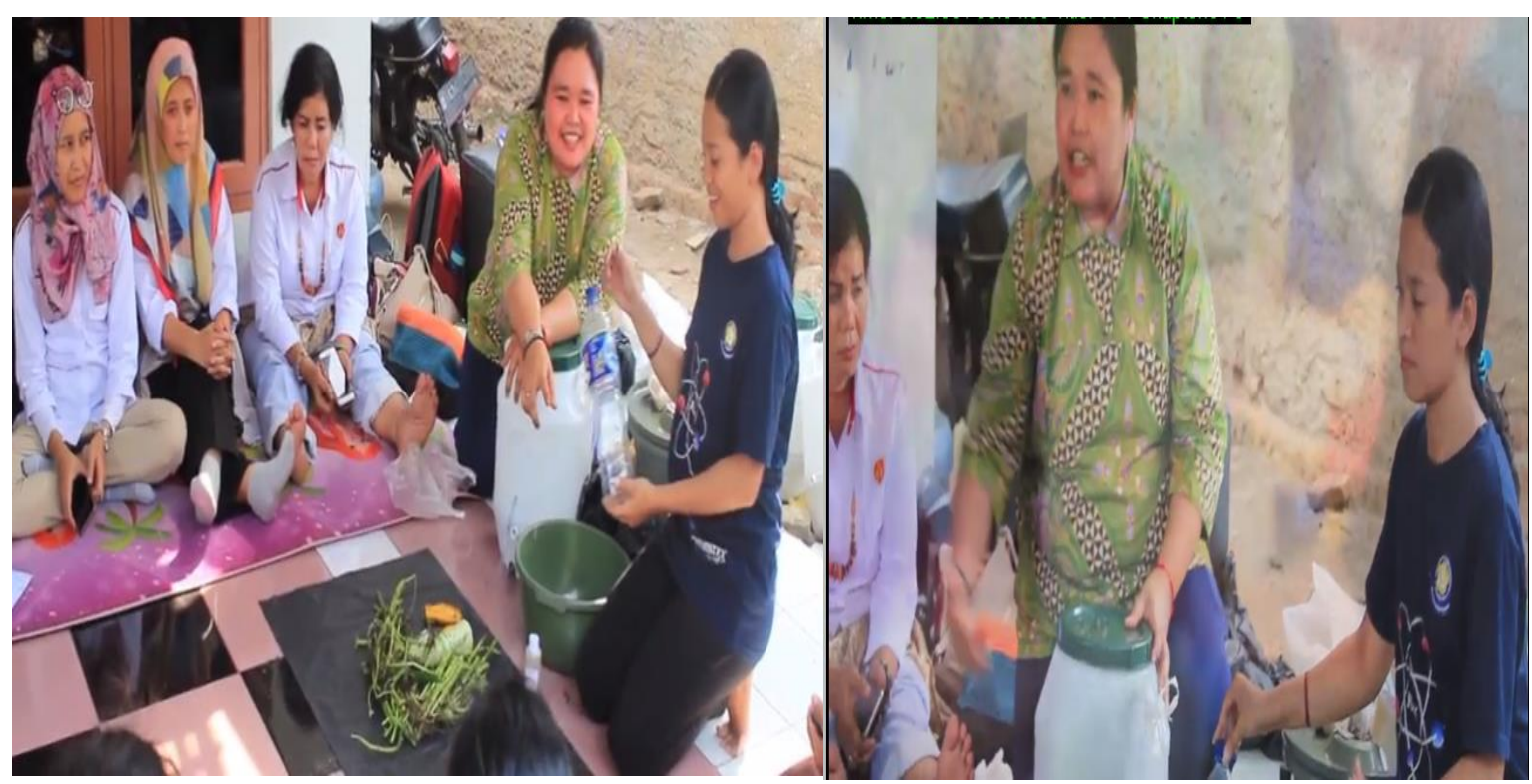

Gambar 3. Proses pengolahan sampah limbah rumah tangga menjadi pupuk organik cair

Pada saat kegiatan, peserta mengikuti dengan antusias dan aktif. Pada akhir diskusi dilakukan penyebaran angket, dari hasil instrumen angket yang disebar, diperoleh informasi bahwa masyarakat Sukajaya telah memahami cara pengolahan sampah limbah rumah tangga menjadi pupuk organik. Adanya keinginan untuk melakukan kegiatan pengolahan sampah limbah rumah tangga menjadi pupuk organik secara berkala dan berkelanjutan

\section{SIMPULAN}

Kegiatan peningkatan daya dukung lingkungan difokuskan untuk mengajak dan merubah perilaku masyarakat untuk peduli terhadap lingkungan sekitar. Diawali dengan sampah atau limbah domestik. Pelaksanaan ini perlu dilakukan dengan analisis situasi dan penelusuran informasi permasalahan untu mencari faktor-faktor penyebab. Pembuatan pupuk organik merupakan salah satu sarana 
untuk mengajak warga agar peduli dengan memanfaatkan limbah yang dimilikinya tanpa harus mengeluarkan biaya yang berlebih.

\section{UCAPAN TERIMAKASIH}

Ucapan terimakasih kami sampaikan kepada:

1. Pemerintah melalui Lembaga Layanan Pendidikan Tinggi Wilayah III (LLDikti III), yang telah mengikursertakan ketiga universitas (UKI, UMJ, UHAMKA) yang tergabung dalam sektor 18 .

2. Ketiga universitas (UKI,UMJ dan UHAMKA) yang memberikan dukungan penuh terhadap pelaksanaan kegiatan

3. Universitas Mercu Buana sebagai koordinator sektor yang secara aktif mengkoordinir pelaksanaan kegiatan dan universitas lainnya (UNKRIS, STIAMI, LSPR dan MH. Thamrin) yang juga memberi dukungan dan semangat penuh dalam pelaksanaan kegiatan.

\section{REFERENSI}

Bukit, N. T., \& Yusuf, I. A. (2002). Beban pencemaran limbah industri dan status kualitas air sungai Citarum. Jurnal Teknologi Lingkungan, 3(2), 98-106..

Herawati, D. A., \& Wibawa, A. A. (2010).

Pengaruh pretreatment jerami padi pada produksi biogas dari jerami padi dan sampah sayur sawi hijau secara batch. Jurnal rekayasa proses, 4(1), 25-29.

Indriyanti, D. R., Banowati, E., \& Margunani, M. (2015). Pengolahan Limbah Organik Sampah Pasar Menjadi Kompos. Jurnal Abdimas, 19 (1).

Irmawan, I. (2018). Membangun Karakter Masyarakat yang Sadar Akan Sampah dan Lingkungan Sungai Citarum di Kecamatan Astana Anyar Kotamadya Bandung. EDUCARE, 2730.

Ruslinda, Y. (2014). Pengelolaan Sampah Kering Layak Jual Dengan Sistem Bank Sampah Di Kampus Universitas Andalas Padang. Jurnal Dampak, 11 (2), 96-109. 